\title{
ANALISIS PENYEBAB KETERLAMBATAN PEKERJAAN KONSTRUKSI JEMBATAN
}

\author{
Khoirul $^{1)}$, Hendrik Pristianto ${ }^{2)}$, Muhammad Rusmin ${ }^{3)}$ \\ ${ }^{1,2,3)}$ Program Studi Teknik Sipil Universitas Muhammadiyah Sorong
}

\begin{abstract}
ABSTRAK
Setiap proyek konstruksi lazimnya mempunyai rencana pelaksanaan dan jadwal pelaksanaan yang tertentu, kapan pelaksanaan proyek tersebut harus dimulai, kapan harus diselesaikan dan bagaimana proyek tersebut akan dikerjakan, serta bagaimana penyediaan sumberdayanya.Namun dalam proses pelaksanaan tersebut, sering terjadi hambatan - hambatan yang tidak diketahu isebelumnya. Untuk itu kiranya perlu dilakukan penelitian untuk mengetahui faktor-faktor penyebab keterlambatan penyelesaian proyek agar waktu penyelesaian proyek sesuai dengan rencana. Maksud dan tujuan penelitian ini Untuk mengetahui faktor-faktor penyebab keterlambatan pekerjaan konstruksi jembatan Klamalu Kabupaten Sorong, merangking faktor-faktor keterlambatan tersebut, serta mengetahui persepsi responden terhadap faktor-faktor penyebab keterlambatan. Metode yang digunakan dalam penelitian ini adalah metode penelitian kuantitatif dengan pengolahan data menggunakan SPSS. Peneliti mengambil sampel 11 responden yang terdiri dari penyedia jasa, pengguna jasa dan konsultan pengawas pada pekerjaan konstruksi Jembatan Klamalu Kabupaten Sorong. Hasil dari penelitan ini ialah faktor-faktor keterlambatan konstruksi Jembatan Klamalu Kabupaten Sorong setelah di rangking sebagai berikut Cuaca buruk (hujan deras / lokasi tergenang), Tidak memenuhi perencanaan awal proyek, Produktivitas tidak optimal oleh kontraktor, Mengalami gangguan diluar proyek,Keterlambatan pengiriman bahan. Penelitian ini juga menyimpulkan bahwa tidak ada perbedaan persepsi responden berdasarkan jabatan responden setelah dilakukan Uji Chi Square dimana nilai asymptotic signifikansi lebih besar dari 0.05 atau Ho diterima.
\end{abstract}

Kata Kunci : Faktor keterlambatan proyek, Jembatan, Ranking, Responden.

\section{PENDAHULUAN Latar Belakang}

Setiap proyek konstruksi lazimnya mempunyai rencana pelaksanaan dan jadwal pelaksanaan yang tertentu, kapan pelaksanaan proyek tersebut harus dimulai, kapan harus diselesaikan dan bagaimana proyek tersebut akan dikerjakan, serta bagaimana penyediaan sumberdaya-nya. Suatu proyek cenderung akan mengalami keterlambatan apabila perencanaan dan pengendalian tidak dilakukan dengan tepat. Berbagai hal dapat terjadi dalam proyek konstruksi yang dapat menyebabkan bertambahnya waktu pengerjaan, sehingga penyelesaian proyek menjadi terlambat. Menurut Alifen et al. keterlambatan pelaksanaan konstruksi sering kali menjadi sumber perselisihan antara kontraktor dengan pemilik dan menurunnya kredibilitas maupun pembengkakan biaya(Alifen et al dalam Harry Kurniawan, 2014:5). Pada kenyataannya hal ini terjadi, sehingga perlu dilakukan suatu analisis yang lebih mendalam sebagai langkah antisipasi.

Seringkali dalam pelaksanaan proyek terjadi keterlambatan yang tidak diinginkan dan tidak di ketahui sebelumnya. Keterlambatan tersebut sangat merugikan pihak-pihak terkait, kontraktor maupun pemilik proyek itu sendiri. Keppres No. 61 tahun 2004 menyebutkan bahwa denda (sanksi finansial) dapat dikenakan penyedia jasa bila tidak dapat melaksanakan proyek sesuai waktu yang tersedia dalam kontrak (dalam Suyatno, 2010:13).

Keterlambatan pelaksanaan proyek memberikan pengaruh yang cukup berarti terhadap biaya.Tambahan biaya yang harus disediakan oleh penyedia jasa baik berupa biaya langsung dan biaya tidak langsung merupakan suatu keharusan untuk mengejar keterlambatan pelaksanaan proyek demi nama 
baik sebuah perusahaan. Tidak jarang di temukan suatu proyek yang terkadang biaya tidak langsungnya lebih besar dari biaya langsung. Biaya tidak langsung ini merupakan biaya overhead, yang berkaitan dengan proyek

Pada penelitian ini akan dianalisis mengenai penyebab keterlambatan pelaksanaan pekerjaan proyek konstruksi jembatan studi kasus jembatan klamalu kabupaten sorong. Analisis penyebab keterlambatan ini penting supaya penyedia jasa dan pihak pihak yang terkait dalam jasa konstruksi dapat mengambil langkah dan solusi yang tepat untuk mengatasi problem keterlambatan pelaksanaan pekerjaan yang sering berulang dan berakibat pada peningkatan biaya.

\section{Tujuan Penelitian}

Tujuan penelitian ini adalah :

1. Untuk mengetahui apa saja faktor-faktor penyebab keterlambatan pekerjaan konstruksi jembatan Klamalu Kabupaten Sorong

2. Untuk mengetahui Bagaimana peringkat (rangking) faktor-faktor yang mempengaruhi keterlambatan waktu pada proyek pembangunan jembatan klamalu Kabupaten Sorong

3. Untuk mengetahui Bagaimana persepsi responden terhadap faktor-faktor penyebab keterlambatan penyelesaian proyek jembatan Kalamalu Kabupaten Sorong

\section{METODE PENELITIAN}

\section{Teknik Pengolahan dan Analisa Data}

Peneletian ini dalambentuk penelitian kuantitatif. Penelitian kuantitatif adalah definisi, pengukuran data kuantitatif dan statistik objektif melalui perhitungan ilmiah berasal dari sampel orang-orang atau penduduk yang diminta menjawab atas sejumlah pertanyaan tentang survei untuk menentukan frekuensi dan persentase tanggapan mereka. Penelitian ini menitik beratkan pengamatan berstruktur yang di lakukan di Jembatan Klamalu 1.

Berikut ini adalah teknik pengumpulan data yang digunakan selama penelitian berlangsung :

\section{Kuesioner}

Kuesioner dalam penelitian ini berisi mengenai faktor-faktor yang menjadi penyebab keterlambatan pekerjaan struktur.

Tabel 2 : Rencana Kuesioner

\begin{tabular}{|c|c|c|c|c|c|}
\hline No & $\begin{array}{l}\text { Faktor- } \\
\text { faktor } \\
\text { Keterlamb } \\
\text { atan } \\
\text { Proyek }\end{array}$ & $\begin{array}{l}\text { Tida } \\
\mathbf{k} \\
\text { Berp } \\
\text { enga } \\
\text { ruh }\end{array}$ & $\begin{array}{l}\text { Agak } \\
\text { Berpe } \\
\text { ngaru } \\
\text { h }\end{array}$ & $\begin{array}{l}\text { Berpeng } \\
\text { aruh }\end{array}$ & $\begin{array}{l}\text { Seangat } \\
\text { Berpengar } \\
\text { uh }\end{array}$ \\
\hline 1 & $\begin{array}{l}\text { Kurangnya } \\
\text { keahlian } \\
\text { tenaga } \\
\text { kerja }\end{array}$ & & & & \\
\hline 2 & $\begin{array}{l}\text { Perubahan } \\
\text { metode } \\
\text { kerja oleh } \\
\text { kontraktor }\end{array}$ & & & & \\
\hline 3 & $\begin{array}{l}\text { Kekuranga } \\
\mathrm{n} \text { tenaga } \\
\text { kerja }\end{array}$ & & & & \\
\hline 4 & $\begin{array}{l}\text { Keterlamba } \\
\text { tan } \\
\text { pengiriman } \\
\text { bahan } \\
\text { (utama) }\end{array}$ & & & & \\
\hline 5 & $\begin{array}{l}\text { Mobilisasi } \\
\text { alat }\end{array}$ & & & & \\
\hline 6 & $\begin{array}{l}\text { Perbaikan } \\
\text { pekerjaan }\end{array}$ & & & & \\
\hline 7 & $\begin{array}{l}\text { Kerusakan } \\
\text { bahan } \\
\text { ditempat } \\
\text { penyimpan } \\
\text { an }\end{array}$ & & & & \\
\hline 8 & $\begin{array}{l}\text { Keterlamb } \\
\text { atan } \\
\text { penutupan } \\
\text { arus } \\
\text { lalulintas }\end{array}$ & & & & \\
\hline 9 & $\begin{array}{l}\text { Ketersedia } \\
\text { an } \\
\text { keuangan } \\
\text { selama } \\
\text { pelaksanaa } \\
\text { n }\end{array}$ & & & & \\
\hline 10 & $\begin{array}{l}\text { Kurangnya } \\
\text { monitor } \\
\text { dan kendali }\end{array}$ & & & & \\
\hline 11 & $\begin{array}{l}\text { Produktivit } \\
\text { as tidak } \\
\text { optimal } \\
\text { oleh } \\
\text { kontraktor }\end{array}$ & & & & \\
\hline 12 & Mengalami & & & & \\
\hline
\end{tabular}




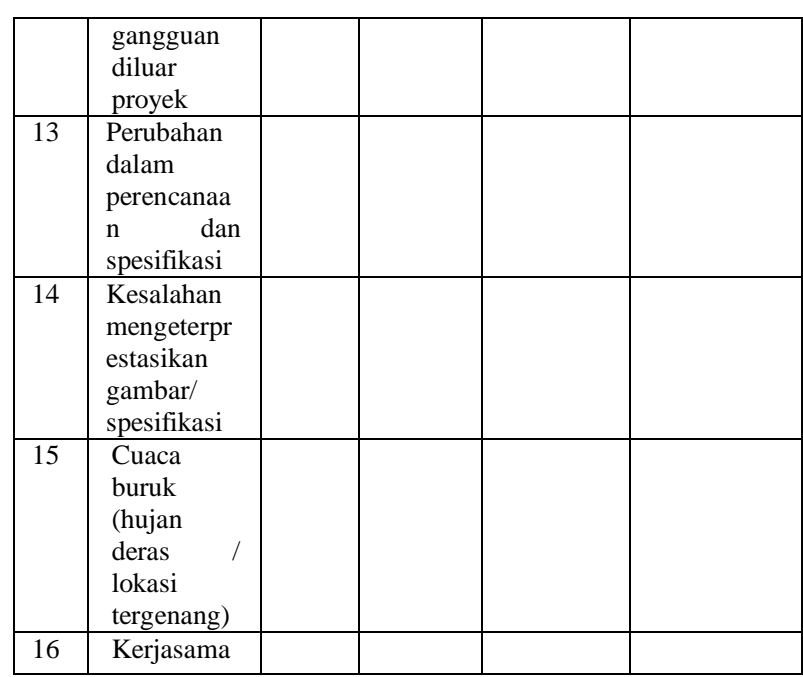

\section{- Uji Validitas}

Uji validitas merupakan tingkat keandalan dan kesahihan alat ukur yang digunakan. Intrumen ikatakan valid berarti menunjukkan alat ukur yang dipergunakan untuk mendapatkan data itu valid atau dapat digunakan untuk mengukur apa yang seharusnya di ukur (Sugiyono dalam Arlen Tandy Soeseno, 2017:31). Dengan demikian, instrumen yang valid merupakan instrumen yang benar-benar tepat untuk mengukur apa yang hendak di ukur.Secara umum ada dua rumus atau cara Uji Validitas yaitu dengan Korelasi Bevariate Pearson dan Correlated Item-Total Correlation. Korelasi Bevariate Pearson adalah salah satu rumus yang dapat digunakan untuk melakukan uji validitas data dengan program SPSS dengan demikian penulis menggunakan Rumus Bivariate Pearson (Korelasi Pearson Product Moment) dalam melakukan Uji Validitas, maka digunakan rumus persamaan

$$
\left.r_{11=\left(\frac{n}{n-1}\right)}\right)\left(1-\frac{\sum s_{i}^{2}}{s_{t}^{2}}\right)
$$

Keterangan:

$r_{11}=$ Reliabilitas instrument

$n=$ Jumlah item pertanyaan yang diuji

$\sum s_{i}^{2}=$ Jumlah varian skor tiap item

$s_{t}^{2}=$ Varian total

\begin{tabular}{|l|l|l|l|l|l|}
\hline & $\begin{array}{l}\text { kurang } \\
\text { optimal }\end{array}$ & & & & \\
\hline 17 & $\begin{array}{l}\text { Keterlamb } \\
\text { atan } \\
\text { pembayara } \\
\text { n oleh } \\
\text { Owner }\end{array}$ & & & & \\
\hline 18 & $\begin{array}{l}\text { Kesalahan } \\
\text { pengelolaa } \\
\text { n material }\end{array}$ & & & & \\
\hline 19 & $\begin{array}{l}\text { Perencanaa } \\
\text { n schedule } \\
\text { yang tidak } \\
\text { tepat }\end{array}$ & & & & \\
\hline 20 & $\begin{array}{l}\text { Tidak } \\
\text { memenuhi } \\
\text { perencanaa } \\
\text { n awal } \\
\text { proyek }\end{array}$ & & & & \\
& & & & \\
\hline
\end{tabular}

Analisis ini dengan cara mengkorelasikan masing-masing skor item dengan skor total. Pengujian menggunakan uji dua pihak dengan taraf signifikansi 0,05 . Kriteria pengujian adalah sebagai berikut:

- Jika $\mathrm{r}$ hitung $\geq \mathrm{r}$ tabel (uji dua pihak dengan sig. 0,05) maka instrumen atau item-item pertanyaan berkorelasi signifikan terhadap skor total (dinyatakan valid).

- Jika $r$ hitung $<\mathrm{r}$ tabel (uji dua sisi dengan sig. 0,05) maka instrumen atau itemitem pertanyaan tidak berkorelasi signifikan terhadap skor total (dinyatakan tidak valid).

\section{- Uji Reliabilitas}

Uji Reliabilitas adalah data untuk mengukur suatu kuesioner yang merupakan indikator dari variabel atau konstruk. Suatu kuesioner dikatakan reliabel atau handal jika jawaban seseorang terhadap pernyataan adalah konsisten atau stabil dari waktu ke waktu.

Jika nilai alpha $>0,7$ artinya reliabilitas mencukupi (sufficient reliability) sementara jika alpha >0,80 ini mensugestikan seluruh item reliabel dan seluruh tes secara konsisten secara internal karena memiliki reliabilitas yang kuat. Atau, ada pula yang memaknakannya jika alpha > 0,90 maka reliabilitas sempurna. Jika alpha antara 0,70 0,90 maka reliabilitas tinggi. Jika alpha antara $0,50-0,70$ maka reliabilitas moderat. Jika alpha $<0,50$ maka reliabilitas rendah. Jika 
alpha rendah, kemungkinan satu atau beberapa item tidak reliabel.

\section{- Analisis Data}

Setelah proses pengumpulan data, tahapan selanjutnya adalah proses analisis data. Dalam proses ini sering kali digunakan statistik karena memang salah satu fungsi statistik adalah menyederhanakan data.

Adapun metode analisis yang akan digunakan antara lain :

\section{- Menentukan Skor Terhadap Pernyataan Kuesioner}

Dalam penelitian ini skala pengukuran data memiliki skala ordinal yang menunjukkan perbedaan tingkatan subyek secara kuantitatif, seperti data yang dinyatakan dalam bentuk peringkat atau ranking. Persepsi responden dapat diurut menjadi : Tidak berpengaruh diberi nilai 0 ; agak berpengaruh diberi nilai 1 ; berpengaruh diberinilai 2 ; sangat berpengaruh diberi nilai 3.

\section{- Menentukan Ranking Pada Jawaban Responden}

Dari hasil indeks kepentingan ini akan dihasilkan peringkat dari masing- masing faktor penyebab keterlambatan proyek Jembatan (Furqon dalam Suyatno, 2014:40) faktor penilaian pada harga rata-rata dibuat batasan sebagai berikut: harga rata -rata kurang dari 0,5 dianggap tidak berpengaruh, $0,5 \mathrm{~s} / \mathrm{d} 1,5$ dianggap agak berpengaruh, lebih besar 1,5 s/d 2,5 dianggap berpengaruh lebih besar 2,5 s/d 3,0 dianggap sangat berpengaruh. Mengingat data yang akan diolah cukup banyak serta untuk mempercepat proses pengolahan data, maka penulis menggunakan bantuan computer SPSS for Windows.

\section{- Menentukan Persepsi Responden dengan Chi Square}

Untuk mengetahui ada tidaknya perbedaan persepsi responden terhadap foktor keterlambatan proyek konstruksi jembatan yang disebabkan oleh faktor material dipakai uji Chi-Square. Uji Chi-Square merupakan metode statistic non parametric yang digunakan untuk menguji ada tidaknya hubungan antara dua variable lebih yang berskala ordinal Untuk pengujian hipotesis, dengan rumus seperti persamaan :

$$
X^{2}=\Sigma \frac{(f o-f e)^{2}}{f e}
$$

Keterangan :

$\mathrm{X}^{2}=$ Nilai Chi Kuadrat

fo $=$ frekuensi yang diobservasi (frekuensi

empiris)

$\mathrm{fe}=$ frekuensi yang diharapkan(frekuensi teoritis)

$$
\text { Rumus } f e=\frac{(\Sigma f k) x(\Sigma f b)}{\Sigma r}
$$

Keterangan :

$\mathrm{fe}=$ frekuensi yang diharapkan(frekuensi teoritis)

$\Sigma \mathrm{fk}=$ Jumlah frekuensi pada kolom

$\Sigma \mathrm{fb}=$ Jumlah frekuensi pada baris

$\Sigma \mathrm{r}=$ Jumlah Keseluruhan baris atau kolom.

Untuk menguji hipotesis nol (Ho) disusun pula hipotesis alternative (H1) sebagai berikut :

Ho : Faktor perbedaan jabatan responden, tidak menyebabkan perbedaan persepsi responden terhadap faktor penyebab keterlambatan penyelesaian proyek Jembatan Klamalu 1 Kabupaten Sorong.

H1 : Faktor perbedaan jabatan responden, yang menyebabkan perbedaan persepsi responden terhadap faktor penyebab keterlambatan penyelesaian proyek Jembatan Klamalu 1 Kabupaten Sorong.

Selanjutnya dasar pengambilan keputusan bisa dengan membandingkan antara Chi-Square hitung dan Chi-Square tabel. Jika Chi-Square hitung < Chi-Square tabel, maka Ho diterima. Silain itu bisa juga berdasarkan 
probabilitas yang dinyatakan dengan angka Asymp. Sig / asymptotic significance. Jika probabilitas $>0.05$, maka Ho diterima, jika probabilitas < 0.05, maka Ho ditolak.

Mengingat data yang akan diolah cukup banyak serta untuk mempercepat proses pengolahan data, maka penulis menggunakan bantuan computer SPSS for Windows.

\section{HASIL PENELITIAN DAN PEMBAHASAN}

- Faktor-Faktor

Keterlambatan Proyek
Klamalu

Pada penelitian ini respondennya adalah penyedia jasa, pengguna jasa dan konsultan pengawas lapangan yang menangani proyek yang sedang berlangsung, sehingga diharapkan jawabannya lebih aktual. Dengan alasan itulah kuesioner disebarkan kepada para responden yang terlibat dalam pelaksanaan pembangunan proyek jembatan klamalu.

Adapun jumlah penyebaran kuesioner yang direncanakan sebanyak 11 responden secara umum bisa terpenuhi. Dalam prakteknya responden sangat sulit meluangkan waktu untuk mengisi kuesioner karena kesibukan. Sebelum melakukan pengisian kuesioner, terlebih dahulu dijelaskan maksud dan tujuan dari penelitian ini, peneliti membagikan penyebaran kuesioner langsung dengan tenaga ahli dari pihak penyedia jasa, pengguna jasa dan konsultan pengawas. Dari sejumlah kuesioner yang disebarkan karena terbatasnya waktu, kuisioner yang bisa terkumpul sejumlah 11 buah.
Tabel 1 : Hasil Uji Validitas Dari Jawaban Responden

\begin{tabular}{|c|c|c|c|c|}
\hline No & $\begin{array}{l}\text { Faktor- } \\
\text { Faktor } \\
\text { Penyebab } \\
\text { Keterlambata } \\
\text { n }\end{array}$ & $\begin{array}{l}\mathbf{r} \\
\text { hitung }\end{array}$ & $\begin{array}{l}\mathbf{r} \\
\text { tabel } \\
(\text { taraf } \\
5 \%)\end{array}$ & Ket. \\
\hline 1 & $\begin{array}{l}\text { Kurangnya } \\
\text { keahlian } \\
\text { tenaga kerja }\end{array}$ & 0,907 & 0,666 & Valid \\
\hline 2 & $\begin{array}{l}\text { Perubahan } \\
\text { metode kerja } \\
\text { oleh } \\
\text { kontraktor }\end{array}$ & 0,714 & 0,666 & Valid \\
\hline 3 & $\begin{array}{l}\text { Kekurangan } \\
\text { tenaga kerja }\end{array}$ & 0,889 & 0,666 & Valid \\
\hline 4 & $\begin{array}{l}\text { Keterlambatan } \\
\text { pengiriman } \\
\text { bahan (utama) }\end{array}$ & 0,873 & 0,666 & Valid \\
\hline 5 & Mobilisasi alat & 0,897 & 0,666 & Valid \\
\hline 6 & $\begin{array}{l}\text { Perbaikan } \\
\text { pekerjaan }\end{array}$ & 0,923 & 0,666 & Valid \\
\hline 7 & $\begin{array}{l}\text { Kerusakan } \\
\text { bahan } \\
\text { ditempat } \\
\text { penyimpanan }\end{array}$ & 0,945 & 0,666 & Valid \\
\hline 8 & $\begin{array}{l}\text { Keterlambatan } \\
\text { penutupan } \\
\text { arus lalulintas }\end{array}$ & 0,902 & 0,666 & Valid \\
\hline 9 & $\begin{array}{l}\text { Ketersediaan } \\
\text { keuangan } \\
\text { selama } \\
\text { pelaksanaan }\end{array}$ & 0,830 & 0,666 & Valid \\
\hline 10 & $\begin{array}{l}\text { Kurangnya } \\
\text { monitor dan } \\
\text { kendali }\end{array}$ & 0,806 & 0,666 & Valid \\
\hline 11 & $\begin{array}{l}\text { Produktivitas } \\
\text { tidak optimal } \\
\text { oleh } \\
\text { kontraktor }\end{array}$ & 0,720 & 0,666 & Valid \\
\hline 12 & $\begin{array}{l}\text { Mengalami } \\
\text { gangguan } \\
\text { diluar proyek }\end{array}$ & 0,916 & 0,666 & Valid \\
\hline 13 & $\begin{array}{l}\text { Perubahan } \\
\text { dalam } \\
\text { perencanaan } \\
\text { dan spesifikasi }\end{array}$ & 0,902 & 0,666 & Valid \\
\hline 14 & $\begin{array}{l}\text { Kesalahan } \\
\text { mengeterprest } \\
\text { asikan } \\
\text { gambar/ } \\
\text { spesifikasi }\end{array}$ & 0,811 & 0,666 & Valid \\
\hline 15 & $\begin{array}{l}\text { Cuaca buruk } \\
\text { (hujan deras / } \\
\text { lokasi } \\
\text { tergenang) }\end{array}$ & 0,787 & 0,666 & Valid \\
\hline 16 & Kerjasama & 0,755 & 0,666 & Valid \\
\hline
\end{tabular}




\section{Jurnal Rancang Bangun 2(2)27-36 2017}

\begin{tabular}{|l|l|l|l|l|}
\hline & $\begin{array}{l}\text { kurang } \\
\text { optimal }\end{array}$ & & & \\
\hline $\mathbf{1 7}$ & $\begin{array}{l}\text { Keterlambatan } \\
\text { pembayaran } \\
\text { oleh Owner }\end{array}$ & 0,831 & 0,666 & Valid \\
\hline $\mathbf{1 8}$ & $\begin{array}{l}\text { Kesalahan } \\
\text { pengelolaan } \\
\text { material }\end{array}$ & 0,826 & 0,666 & Valid \\
\hline $\mathbf{1 9}$ & $\begin{array}{l}\text { Perencanaan } \\
\text { schedule yang } \\
\text { tidak tepat }\end{array}$ & 0,780 & 0,666 & Valid \\
\hline $\mathbf{2 0}$ & $\begin{array}{l}\text { Tidak } \\
\text { memenuhi } \\
\text { perencanaan } \\
\text { awal proyek }\end{array}$ & 0,740 & 0,666 & Valid \\
\hline
\end{tabular}

Sumber : Hasil Penelitian Perhitungan Uji Validitas Maret 2017

Tabel 1 diatas menunjukkan bahwa hasil $r$ hitung dari jawaban responden lebih besar dari $r$ tabel, berarti jawaban dari masingmasing responden valid.

Tabel 2 : Hasil Uji Reabilitas Dari Jawaban

\begin{tabular}{|l|l|c|}
\hline \multicolumn{3}{|c|}{ Responden } \\
\hline No & Variabel & $\begin{array}{c}\mathbf{r} \\
\text { hitung }\end{array}$ \\
\hline $\mathbf{1}$ & $\mathrm{X}$ & 0,976 \\
\hline
\end{tabular}

Sumber : Hasil Penelitian Perhitungan Uji Realibilitas Maret 2017

\section{- Peringkat (ranking) faktor-faktor penyebab Keterlambatan Proyek Jembatan Klamalu}

Pada bagian ini ditentukan item yang mempengaruhi faktor keterlambatan proyek Jembatan Klamalu I, kemudian dengan menggunakan perhitungan indeks kepentingan sehingga diketahui peringkat atau ranking item-item dari jawaban responden

Tabel 3 : Hasil perhitungan Mean Faktor Penyebab Keterlambatan Penyelesaian Proyek

\begin{tabular}{|l|l|c|}
\hline No & \multicolumn{1}{|c|}{$\begin{array}{c}\text { Faktor-Faktor } \\
\text { Penyebab } \\
\text { Keterlambatan }\end{array}$} & Mean \\
\hline $\mathbf{1}$ & $\begin{array}{l}\text { Kurangnya keahlian } \\
\text { tenaga kerja }\end{array}$ & 2,55 \\
\hline $\mathbf{2}$ & $\begin{array}{l}\text { Perubahan metode kerja } \\
\text { oleh kontraktor }\end{array}$ & 2,45 \\
\hline $\mathbf{3}$ & Kekurangan tenaga kerja & 2,36 \\
\hline
\end{tabular}

\begin{tabular}{|c|c|c|}
\hline 4 & $\begin{array}{l}\text { Keterlambatan } \\
\text { pengiriman } \\
\text { (utama) }\end{array}$ & 2,27 \\
\hline 5 & Mobilisasi alat & 2,18 \\
\hline 6 & Perbaikan pekerjaan & 2,09 \\
\hline 7 & $\begin{array}{l}\text { Kerusakan bahan } \\
\text { ditempat penyimpanan }\end{array}$ & 2,00 \\
\hline 8 & $\begin{array}{l}\text { Keterlambatan } \\
\text { penutupan arus lalulintas }\end{array}$ & 1,91 \\
\hline 9 & $\begin{array}{l}\text { Ketersediaan keuangan } \\
\text { selama pelaksanaan }\end{array}$ & 1,82 \\
\hline 10 & $\begin{array}{l}\text { Kurangnya monitor dan } \\
\text { kendali }\end{array}$ & 1,73 \\
\hline 11 & $\begin{array}{l}\text { Produktivitas tidak } \\
\text { optimal oleh kontraktor }\end{array}$ & 1,64 \\
\hline 12 & $\begin{array}{ll}\text { Mengalami } & \text { gangguan } \\
\text { diluar proyek }\end{array}$ & 1,55 \\
\hline 13 & $\begin{array}{lr}\begin{array}{l}\text { Perubahan } \\
\text { perencanaan }\end{array} & \text { dalam } \\
\text { spesifikasi } & \text { dan } \\
\end{array}$ & 1,45 \\
\hline 14 & $\begin{array}{l}\text { Kesalahan } \\
\text { mengeterprestasikan } \\
\text { gambar/ spesifikasi }\end{array}$ & 1,36 \\
\hline 15 & $\begin{array}{l}\text { Cuaca buruk (hujan } \\
\text { deras / lokasi tergenang) }\end{array}$ & 1,27 \\
\hline 16 & $\begin{array}{l}\text { Kerjasama kurang } \\
\text { optimal }\end{array}$ & 1,18 \\
\hline 17 & $\begin{array}{l}\text { Keterlambatan } \\
\text { pembayaran oleh } \text { Owner }\end{array}$ & 1,09 \\
\hline 18 & $\begin{array}{l}\text { Kesalahan pengelolaan } \\
\text { material }\end{array}$ & 1,09 \\
\hline 19 & $\begin{array}{l}\text { Perencanaan schedule } \\
\text { yang tidak tepat }\end{array}$ & 1,00 \\
\hline 20 & $\begin{array}{lr}\text { Tidak } & \text { memenuhi } \\
\text { perencanaan } & \text { awal } \\
\text { proyek } & \\
\end{array}$ & 0,91 \\
\hline
\end{tabular}

Sumber : Hasil Penelitian Perhitungan Nilai Mean Maret 2017.

Selanjutnya untuk memberi penilaian pada harga rata-rata dibuat batasan sebagai berikut : harga rata -rata kurang dari 0,50 (tidak berpengaruh), $0,51-1,49$ (agak berpengaruh), 1,50 - 2,49 (berpengaruh), 2,50 - 3,00 (sangat berpengaruh), sebagaimana terlihat pada tabel 4 dibawah ini.

Tabel 4: Penjelasan arti interval Nilai Mean

\begin{tabular}{|c|c|c|}
\hline Interval Nilai & Arti & Frekuensi \\
\hline$<0,50$ & $\begin{array}{c}\text { Tidak } \\
\text { Berpengaruh }\end{array}$ & - \\
\hline $0,51-1,49$ & $\begin{array}{c}\text { Agak } \\
\text { Berpengaruh }\end{array}$ & - \\
\hline $1,50-2,50$ & Berpengaruh & 20 \\
\hline
\end{tabular}




\begin{tabular}{|r|r|c|}
\hline $2,51-3,00$ & $\begin{array}{c}\text { Sangat } \\
\text { Berpengaruh }\end{array}$ & - \\
\hline & Jumlah & 20 \\
\hline
\end{tabular}

Sumber : Hasil Penelitian arti interval nilai mean Maret 2017

Setelah ditketahui nilai mean pada hasil penelitian maka selanjutnya menentukan rangking dengan bantuan Microsoft Excel 2007 dan didapatkan hasil perhitungan sebagai berikut:

Tabel 5 : Rangking Faktor Penyebab Keterlambatan Penyelesaian Proyek

\begin{tabular}{|c|c|c|}
\hline No & $\begin{array}{c}\text { Faktor-Faktor Penyebab } \\
\text { Keterlambatan }\end{array}$ & Ranking \\
\hline 1 & $\begin{array}{l}\text { Cuaca buruk (hujan deras / } \\
\text { lokasi tergenang) }\end{array}$ & 1 \\
\hline 2 & $\begin{array}{l}\text { Produktivitas tidak optimal } \\
\text { oleh kontraktor }\end{array}$ & 2 \\
\hline 3 & $\begin{array}{l}\text { Tidak memenuhi perencanaan } \\
\text { awal proyek }\end{array}$ & 3 \\
\hline 4 & $\begin{array}{l}\text { Mengalami gangguan diluar } \\
\text { proyek }\end{array}$ & 4 \\
\hline 5 & $\begin{array}{l}\text { Ketersediaan keuangan } \\
\text { selama pelaksanaan }\end{array}$ & 5 \\
\hline 6 & $\begin{array}{l}\text { Perubahan metode kerja oleh } \\
\text { kontraktor }\end{array}$ & 6 \\
\hline 7 & Kekurangan tenaga kerja & 7 \\
\hline 8 & Kerjasama kurang optimal & 8 \\
\hline 9 & Perbaikan pekerjaan & 9 \\
\hline 10 & $\begin{array}{l}\text { Kurangnya monitor dan } \\
\text { kendali }\end{array}$ & 10 \\
\hline 11 & $\begin{array}{l}\text { Kesalahan pengelolaan } \\
\text { material }\end{array}$ & 11 \\
\hline 12 & $\begin{array}{l}\text { Perencanaan schedule yang } \\
\text { tidak tepat }\end{array}$ & 12 \\
\hline 13 & $\begin{array}{l}\text { Kurangnya keahlian tenaga } \\
\text { kerja }\end{array}$ & 13 \\
\hline 14 & $\begin{array}{l}\text { Keterlambatan pengiriman } \\
\text { bahan (utama) }\end{array}$ & 14 \\
\hline 15 & Mobilisasi alat & 15 \\
\hline 16 & $\begin{array}{l}\text { Kerusakan bahan ditempat } \\
\text { penyimpanan }\end{array}$ & 16 \\
\hline 17 & $\begin{array}{l}\text { Keterlambatan penutupan } \\
\text { arus lalulintas }\end{array}$ & 17 \\
\hline 18 & $\begin{array}{l}\text { Perubahan dalam } \\
\text { perencanaan danspesifikasi }\end{array}$ & 18 \\
\hline 19 & $\begin{array}{lr}\text { Kesalahan } & \text { mengenter } \\
\text { prestasikan } & \text { gambar/ } \\
\text { spesifikasi } & \\
\end{array}$ & 19 \\
\hline 20 & $\begin{array}{l}\text { Keterlambatan pembayaran } \\
\text { oleh Owner }\end{array}$ & 20 \\
\hline
\end{tabular}

Sumber : Hasil Penelitian Perhitungan Rangking Maret 2017

Dari tabel 10 diatas menunjukkan bahwa peringkat 1 sampai dengan peringkat 5 , yaitu: (1) Cuaca buruk (hujan deras / lokasi tergenang), (2) Produktivitas tidak optimal oleh kontraktor, (3) Tidak memenuhi perencanaan awal proyek, (4) Mengalami gangguan diluar proyek (5) Ketersediaan keuangan selama pelaksanaan, yang memiliki nilai interval antara $1,50-3,00$ dengan peringkat secara berurutan. Kemudian setelah diranking maka diurutkan sesuai tabel 11 adalah sebagai berikut :

Tabel 6 : Ranking Faktor-faktor penyebab keterlambataan Proyek Jembatan Klamalu 1

\begin{tabular}{|c|l|c|}
\hline No & $\begin{array}{l}\text { Faktor-Faktor Penyebab } \\
\text { Keterlambatan }\end{array}$ & Ranking \\
\hline 1 & $\begin{array}{l}\text { Cuaca buruk (hujan deras } \\
\text { / lokasi tergenang) }\end{array}$ & 1 \\
\hline 2 & $\begin{array}{l}\text { Produktivitas tidak } \\
\text { optimal oleh kontraktor }\end{array}$ & 2 \\
\hline 3 & $\begin{array}{l}\text { Tidak memenuhi } \\
\text { perencanaan awal proyek }\end{array}$ & 3 \\
\hline 4 & $\begin{array}{l}\text { Mengalami gangguan } \\
\text { diluar proyek }\end{array}$ & 5 \\
\hline 5 & $\begin{array}{l}\text { keterlambatan penutupan } \\
\text { arus lalu lintas }\end{array}$ \\
\hline
\end{tabular}

Sumber : Hasil Penelitian Perhitungan Rangking Maret 2017

Dari tabel 6 tersebut diatas untuk lebih jelasnya, ranking faktor penyebab keterlambatan penyelesaian proyek hasil kuisioner kemudian dianalisis dan disajikan sebagai berikut dibawah ini :

\section{Ranking 1 : Cuaca buruk (hujan deras / lokasi tergenang)}

Item ini dianggap pengaruh oleh responden karena didalam pelaksanaan pekerjaan jembatan ini tidak bisa dilaksanakan karena sangat dipengaruhi adanya / keadaan cuaca yang baik

\section{Ranking 2 : Produktivitas tidak optimal oleh kontraktor}

Item ini dianggap berpengaruh oleh responden karena menurut pengamatan dilapangan produktivitas baik bila mampu mencapai 
progress yang diinginkan. Namun kenyataannya produktivitas kerja tidak sesuai progress rencana dan mengalami keterlambatan pekerjaan

Ranking 3 : Tidak memenuhi perencanaan awal proyek

Item ini dianggap berpengaruh oleh responden karena apabila pada awal pekerjaan penyedia jasa tidak bisa memenuhi perencanaan awal proyek maka akan menyebabkan pekerjaan tidak sesuai dengan rencana kerja yang telah dijadwalkan.

Ranking 4 : Mengalami gangguan diluar proyek

Item ini dianggap berpengaruh oleh responden karena dengan adanya gangguan maka aktivitas pekerjaan jadi terganggu dan tidak maksimal (ada pun gangguan dalam proyek ini yaitu area pemancangan di lewati jaringan listrik tegangan tinggi ) .

Ranking 5 : Ketersediaan keuangan selama pelaksanaan

Item ini dianggap berpengaruh oleh responden karena ketersediaan keuangan selama pelaksanaan proyek menjadi penyokong keberlangsungan pekerjaan.

\section{- Persepsi Responden Terhadap Faktor Penyebab Keterlambatan Proyek}

Dari hasil penelitian ini untuk diketahui apakah ada perbedaan persepsi responden dalam menilai faktor-faktor penyebab keterlambatan penyelesaian proyek berdasarkan jabatan responden. Hasil penelitian dianalisis dengan mempergunakan Uji Chi Square Untuk mempercepat proses perhitungan dipakai program SPSS for Windows. Dengan demikian dasar pengambilan keputusan diambil berdasarkan angka Asymp Sig. Hasil olahan SPSS sebagaimana dapat dilihat pada lampiran dan dirangkum pada tabel-tabel berikut ini:
Tabel. 7: Persepsi Responden Terhadapa

Faktor Keterlambatan Berdasarkan Jabatan

Responden

\begin{tabular}{|c|c|c|}
\hline No & $\begin{array}{c}\text { Faktor-Faktor Penyebab } \\
\text { Keterlambatan }\end{array}$ & $\begin{array}{l}\text { Asymp } \\
\text { Sig }\end{array}$ \\
\hline 1 & $\begin{array}{l}\text { Cuaca buruk (hujan deras / } \\
\text { lokasi tergenang) }\end{array}$ & 0,560 \\
\hline 2 & $\begin{array}{l}\text { Produktivitas tidak optimal } \\
\text { oleh kontraktor }\end{array}$ & 0,741 \\
\hline 3 & $\begin{array}{l}\text { Tidak memenuhi } \\
\text { perencanaan awal proyek }\end{array}$ & 0,741 \\
\hline 4 & $\begin{array}{l}\text { Mengalami gangguan diluar } \\
\text { proyek }\end{array}$ & 0,741 \\
\hline 5 & $\begin{array}{l}\text { Ketersediaan keuangan } \\
\text { selama pelaksanaan }\end{array}$ & 0,766 \\
\hline 6 & $\begin{array}{l}\text { Perubahan metode kerja oleh } \\
\text { kontraktor }\end{array}$ & 0,431 \\
\hline 7 & Kekurangan tenaga kerja & 0,845 \\
\hline 8 & Kerjasama kurang optimal & 0,550 \\
\hline 9 & Perbaikan pekerjaan & 0,538 \\
\hline $\mathbf{1 0}$ & $\begin{array}{l}\text { Kurangnya monitor dan } \\
\text { kendali }\end{array}$ & 0,358 \\
\hline 11 & $\begin{array}{l}\text { Kesalahan pengelolaan } \\
\text { material }\end{array}$ & 0,355 \\
\hline 12 & $\begin{array}{l}\text { Perencanaan schedule yang } \\
\text { tidak tepat }\end{array}$ & 0,357 \\
\hline 13 & $\begin{array}{l}\text { Kurangnya keahlian tenaga } \\
\text { kerja }\end{array}$ & 0,538 \\
\hline 14 & $\begin{array}{l}\text { Keterlambatan pengiriman } \\
\text { bahan (utama) }\end{array}$ & 0,682 \\
\hline 15 & Mobilisasi alat & 0,682 \\
\hline 16 & $\begin{array}{l}\text { Kerusakan bahan ditempat } \\
\text { penyimpanan }\end{array}$ & 0,411 \\
\hline 17 & $\begin{array}{l}\text { Keterlambatan penutupan } \\
\text { arus lalulintas }\end{array}$ & 0,121 \\
\hline 18 & $\begin{array}{l}\text { Perubahan dalam } \\
\text { perencanaan danspesifikasi }\end{array}$ & 0,121 \\
\hline 19 & $\begin{array}{lr}\text { Kesalahan } & \text { mengenter } \\
\text { prestasikan } & \text { gambar/ } \\
\text { spesifikasi } & \\
\end{array}$ & 0,106 \\
\hline 20 & $\begin{array}{l}\text { Keterlambatan pembayaran } \\
\text { oleh Owner }\end{array}$ & 0,52 \\
\hline
\end{tabular}

Sumber : Hasil perhitungan Penelitian Persepsi Responden Terhadapa Faktor Keterlambatan Berdasarkan Jabatan RespondenMaret 2017

Tabel 7 diatas menjelaskan persepsi responden terhadap faktor penyebab keterlambatan penyelesaian proyek, berdasarkan jabatan responden. Untuk mengetahui ada tidaknya perbedaan persepsi yaitu dengan melihat Asymp Sig. Apabila AsympSig. masing-masing item lebih besar 0.050 maka tidak ada perbedaan persepsi 
berdasarkan Jabata $\mathrm{n}$. Tampak pada tabel 12 menunjukkan seluruh nilai Asymp Sig menunjukkan lebih besar dari 0.05. Artinya tidak ada perbedaan persepsi responden dalam menilai faktor penyebab keterlambatan penyelesaian proyek berdasarkan jabatan responden. Hal ini menunjukkan bahwa 20 item Ho diterima.

\section{PENUTUP}

Kesimpulan yang dapat ditarik pada penelitian ini adalah sebagai berikut : Faktor-faktor penyebab keterlambatan penyelesaian proyek jembatan klamalu 1 Kabupaten Sorong, adalah sebagai berikut: (a) Cuaca buruk (hujan deras / lokasi tergenang), (b) Produktivitas tidak optimal oleh kontraktor; (c) Tidak memenuhi perencanaan awal proyek, (d) Mengalami gangguan diluar proyek, (e) Ketersediaan keuangan selama pelaksanaan, (f) Perubahan metode kerja oleh kontraktor, (g) Kekurangan tenaga kerja, (h) Kerjasama kurang optimal, (i) Perbaikan pekerjaan, (j) Kurangnya monitor dan kendali, (k) Kesalahan pengelolaan material, (l) Perencanaan schedule yang tidak tepat, (m) Kurangnya keahlian tenaga kerja, (n) Keterlambatan pengiriman bahan (utama), (o) Mobilisasi alat, (p) Kerusakan bahan ditempat penyimpanan, (q) Keterlambatan penutupan arus lalulintas, (r) Perubahan dalam perencanaan danspesifikasi, (s) Kesalahan mengenter prestasikan gambar/ spesifikasi,

Keterlambatan pembayaran oleh Owner.

Ranking yang diperoleh dari faktor-faktor penyebab keterlambatan tersebut antara lain : (a) Cuaca buruk (hujan deras / lokasi tergenang), (b) Produktivitas tidak optimal oleh kontraktor, (c) tidak memenuhi perencanaan awal proyek, (d) Mengalami gangguan diluar proyek; (e) Ketersediaan keuangan selama pelaksanaan.

Dari hasil penelitian ini ternyata secara keseluruhan menurut persepsi responden terhadap faktor-faktor penyebab ketelambatan pekerjaan proyek Jembatan
Klamalu 1 berdasarkan Responden dimana nilai asymptotic signifikansi lebih besar dari 0.05 atau Ho diterima yang berarti tidak ada perbedaan persepsi antara Penyedia Jasa, Pengguna Jasa dan Konsultan Pengawas.

\section{REFERENSI}

Amir, Ashadi., 2013. Studi Keandalan Struktur Jembatan Sungai Tello (Lama) Berdasarkan Beban Lalu Lintas Umum Dan Trailer Super Berat Dengan Metode Moving Load. Jurnal Tugas Akhir. 1

Ariefasa, Ryan., 2011. Faktor Penyebab Keterlambatan Pekerjaan Konstruksi Bangunan Gedung Bertingkat Yang Berpengaruh Terhadap Perubahan Anggaran biaya Pada Pekerjaan Struktur. Skripsi Sarjana Teknik Sipil Universitas Indonesia: diterbitkan.

Dwiwinarsih Rina, 2009. Analisis Tingkat Kepuasan Konsumen Terhadap Pelayanan Bakmi Aisy Di Depok. Jurnal Ekonomi Manajemen.

Irika dan Lenggogeni., 2013. Manajemen Konstruksi. Remaja Rosdakarya : Bandung.

Kurniawa, Harry., 2014. Studi Faktor Penghambat Pelaksanaan Konstruksi di Daerah Istimewa Yogyakarta. Jurnal Teknik Sipil Universitas Atamajaya Yogyakarta

Karunia, Meutia Nadia., 2016. Analisis Resiko Keterlambatan Waktu Pada Proyek (Studi Kasus: Pembangunan Jalan Tol Trans Sumatera Bakauheni-Terbanggi Besar). Skripsi Sarjana Teknik Sipil Universitas Lampung: diterbitkan.

Matondang Zulkifli., 2009. Validitas Dan Reliabilitas Suatu Instrumen Penelitian. Jurnal Tabularasa Pps Unimed. 
Nugroho, Bayu Adi., 2012. Analisis Faktor Keterlambatan Proyek Terhadap Pembengkakan Biaya Proyek Pembangunan Gedung Di Surakarta. Skripsi Sarjana Teknik Sipil Universitas Sebelas Maret Surakarta: diterbitkan.

Sianipar, Hasoloan Benget., 2012. Analisis Faktor-Faktor Penyebab Keterlambatan Penyelesaian Konstruksi Pengaruhnya Terhadap Biaya. Skripsi Sarjana Teknik Sipil Universitas Sebelas Maret: diterbitkan.

Silalahi, Ulber., 2010. Metode Penelitian Sosial. PT. Refika Aditama: Jakarta.

Soeseno, Arlen Tandy., 2017. Persepsi Wholesaler Terhadap Bauran Pemasaran Produk Pencil Case Merek Shintoeng Di
Kota Surabaya. Skripsi Sarjana Manajemen Univesitas Katolik Soegijapranata: diterbitkan

Suharto., 2015. Hubungan Antara Produktivitas Pekerja Galangan Dan Teknik Kerja Terhadap Kinerja Graving Dock (Studi Kasus Di Pt. Janata Marina Indah Semarang). Jurnal Teknik Sipil Unaya.

Supriyadi dan Muntohar., 2000. Jembatan. Beta Offset: Yogyakarta.

Suyatno., 2010. Analisis Faktor Penyebab Keterlambatan Penyelesaian Proyek Gedung. Tesis Magister Teknik Sipil Universitas Diponegoro Semarang: diterbitkan 